\title{
Chinese Tourists' Perception of the Tourism Image of North Korea Based on Text Data from Tourism Websites
}

\author{
Rilong $\mathrm{Li}^{1}$, Huanjiong Wang ${ }^{2}(\mathbb{D})$ and Hao Zhang ${ }^{2, *(\mathbb{D})}$ \\ 1 Hotel Management, Qingdao Binhai University, Qingdao 266555, China; 02475@qdbhu.edu.cn \\ 2 Key Laboratory of Land Surface Pattern and Simulation, Institute of Geographic Sciences and Natural \\ Resources Research, Chinese Academy of Sciences, 11A, Datun Road, Chaoyang District, \\ Beijing 100101, China; wanghj@igsnrr.ac.cn \\ * Correspondence: zhanghao@igsnrr.ac.cn
}

Citation: Li, R.; Wang, H.; Zhang, H. Chinese Tourists' Perception of the Tourism Image of North Korea Based on Text Data from Tourism Websites. Sustainability 2021, 13, 12205. https:/ / doi.org/10.3390/su132112205

Academic Editor: Anna Mazzi

Received: 15 October 2021

Accepted: 2 November 2021

Published: 5 November 2021

Publisher's Note: MDPI stays neutral with regard to jurisdictional claims in published maps and institutional affiliations.

Copyright: (c) 2021 by the authors. Licensee MDPI, Basel, Switzerland. This article is an open access article distributed under the terms and conditions of the Creative Commons Attribution (CC BY) license (https:/ / creativecommons.org/licenses/by/ $4.0 /)$.

\begin{abstract}
A good tourism image can significantly enhance the travel willingness and experience of international tourists. Most related research focused on the tourism image perception of worldfamous cities, but research on the tourism image of North Korea is insufficient. We extracted text data from travel notes and reviews on Chinese travel websites. Subsequently, we used text mining and semantic network analysis to investigate Chinese tourists' perception of the tourism image of North Korea. The results of the semantic network analysis show that tourism in North Korea consisted mainly of visits to the main cities and famous scenic spots, always with tour guides. Changes in high-frequency words indicated that Chinese tourists' interest in North Korea's history has weakened in recent years, and their interest in scenic spots and tourism products has increased. The results of the iterative correlation convergence analysis show that the topics relevant to tourists' image of North Korea are composed of representative scenic spots, the Korean War, Kaesong city, the Pyongyang City, people's lives, and other notable experiences. This research makes an empirical case for the study of tourists' perception of the tourism image of North Korea and provides targeted suggestions for the sustainable development of North Korean tourism.
\end{abstract}

Keywords: North Korea; tourism image perception; text mining; semantic network analysis

\section{Introduction}

The image of a tourism destination is a key factor in attracting tourists and creating a local identity [1]. In recent years, competition among tourism destinations has become increasingly fierce. Therefore, the image of a tourism destination has become a core source of competitive advantages [2]. Tourists' perception of a tourism image refers to tourists' comprehensive evaluation and expression of a tourist destination, an important factor for tourists when deciding whether to visit a destination [3]. Capturing the image perception of tourists could provide a theoretical basis for decision-makers to formulate management measures such as tourism industry development and tourism destination planning. Therefore, knowledge of how to accurately grasp the image perception of tourists and potential tourists has become increasingly important [4].

Previous research on the image of tourism destinations mainly adopted the survey method, directly interviewing overseas tourists in their home country. This method is more effective than surveying tourists while they are visiting tourist destinations [5]. However, with the development and application of the internet, big data has become a convenient source for investigating how tourists express their impressions and views about tourism destinations. Online travel diaries and comments reflect tourists' perceptions of tourism destinations [6-9] and have become an important factor influencing potential tourists to visit destinations. Recent studies collected text and content uploaded by tourists to personal social media platforms to analyze tourists' attention to specific items or topics [10]. For example, Dilley [11] analyzed images in tourist brochures from different countries and 
divided the images into five categories: landscape, culture, entertainment activities, and services. Stepchenkova and Morrison [12] used the text analysis method to compare and analyze information from travel websites in the U.S. and Russia and found that Russia's tourism image, as perceived by Americans, is one-sided. Choi et al. [13] assessed the image of Macao as a tourist destination by analyzing content from Macau's official tourism websites and from travel agents' websites.

Most of the methods on the image perception of tourist destinations are limited to the interview. We admit that the interview method is an efficient method for an in-depth understanding of consumer attitudes, motivations, and behaviors, but its disadvantage is that the sample is generally too small to represent a large group. However, this study collected a large amount of network data to compensate for the problem of sample size. In terms of analysis methods, we conducted a semantic network analysis on the data quantitatively to understand the core topics and main concerns of Chinese tourists when they talked about North Korea. Calculating the change in the number of high-frequency words in different periods is more objective and accurate than qualitative study.

Overall, most previous tourism studies focused on popular tourist cities and tourist attractions. However, research related to the tourism image of North Korea is scant. One study found that tourists visiting North Korea were motivated by their desire to understand the country's current situation and to witness the places where their fathers had fought in the Korean War [14]. Due to the influence of the international political situation and its own policies, North Korea has been closed to the outside world, resulting in a poor tourism image and the slow development of tourism. Our study extracted the travel notes and comments about North Korean tourism on Chinese tourism websites over the past 20 years (2000-2019) to provide policy suggestions and a theoretical basis for the sustainable development of North Korea's tourism. The paper used high-frequency word analysis, semantic network analysis, and quadratic assignment procedure (QAP) to assess the image perception of North Korean tourism of Chinese tourists. The results of this study could help to promote an understanding of North Korea's tourism image and put forward recommendations for tourism marketing management.

\section{Literature Review}

\subsection{Study Area}

North Korea, located in the northern half of the Korean peninsula in eastern Asia, is bordered by China to the north, Russia to the northeast, and South Korea to the south. It covers an area of $123,000 \mathrm{~km}^{2}$ and has a population of about 24 million. The administrative division includes one municipality directly under the central government (Pyongyang), two special cities (Nampo and Rason), and nine provinces (South Pyongan, North Pyongan, Chagang, South Hwanghae, North Hwanghae, Kangwon, South Hamgyong, North Hamgyong, and Ryanggang). North Korea has a temperate monsoon climate with an annual average temperature of $8-12{ }^{\circ} \mathrm{C}$, and an average annual precipitation of $1000-1200 \mathrm{~mm}$.

North Korea has a long coastline, beautiful rivers, and mountains. The abundant tourism resources in the country are well known for their unspoiled ecology and for being pollution-free, mysterious, and unique. To date, there are only 24 hotels, including three 5-star hotels in Pyongyang. Pyongyang international airport is the only international airport in North Korea. It is located about $24 \mathrm{~km}$ north of downtown Pyongyang, and there are flights from China, Russia, Thailand, Singapore, Malaysia, and Japan. Trains from Pyongyang to China and Russia run weekly. There is still great potential for the development of tourism in North Korea.

As opposed to the leadership of Kim Jong Il, Kim Jong-un is very willing and actively promotes the development of North Korea, indicating that he tried to determine the direction of North Korea's development as modernization and internationalization [15]. Since Kim Jong-un proposed in April 2018 to implement the new strategic line of "concentrating all forces on the whole party and the country for socialist economic construction", all industries, especially tourism, have made great progress in North Korea. At present, the 
inbound tourism market is the mainstay of North Korea's tourism market. More than $90 \%$ of the foreign tourists received are from China. Therefore, the Chinese market is very important to North Korea, and the perception of the image of North Korea by Chinese tourists has become particularly important. However, due to the comprehensive effects of politics and economy, coupled with the closure of the national system, it still faces problems such as insufficient electricity, lagging transportation, relatively monotonous tourism products, and few evening entertainment projects.

\subsection{Tourism Destination Image Perception}

The tourism destination image was first put forward by Hunt [15] in his doctoral thesis "Image-A Factor in Tourism". Since then, many studies have focused on tourism destination image. Most studies defined tourism destination image from the perspective of tourists' psychology. The prevailing view was that the destination image refers to the sum of people's overall perception of a tourism destination after they have acquired various items of information and knowledge [16-20]. Baloglu and McCleary [21] considered that tourism destination image is a concept that represents tourists' personal attitudes and that it mainly reflects tourists' understanding, emotion, and impression of a tourism destination. Kim [22] also concluded that a tourism destination image is the total of tourists' impressions, thoughts, and feelings about the destination. Bi [23] pointed out that the destination image is tourists' overall perception and subjective impression of the destination's culture, stability, and instability. Grosspietsch [24] also noted that the perception of a tourism destination image is the overall impression, understanding, and evaluation of tourists of a tourism destination, together with their comprehensive understanding and sense of the destination's society, politics, economy, life, culture, and tourism development.

Existing studies have proposed a variety of classification methods for the image of tourism destinations. Echtner and Ritchie [17] believed that tourism destination image could be divided into the functional image (the physical image that can be observed and measured) and the psychological image (psychological perception that cannot be directly observed and measured); the common image (the universal image that tourism destinations have) and the unique image (the unique image that is distinct from other tourist destinations); attributes image (such as the weather, accommodation facilities, and residents' attitudes), and holistic image (the overall image of the tourism destination). However, Baloglu and McCleary [16] provided another classification: original image, induced image, and complex image. The original image refers to the tourism destination image formed by non-advertising media (such as news magazines and television) before the tourists travel to the destination. The induced image is the image produced by purposeful marketing advertisements and other information produced by tourism agencies. The complex image generally refers to the image produced by the tourist experience. The judgment and reaction of tourists to the induced image are affected by the original image [17]. In combination with the above research on tourism destination image, this study defines tourism destination image as the overall impression tourists have of a specific destination.

To date, many studies have used different factors to measure the image of tourism destinations, including tourism activities, landscape, surrounding environment, natural scenery, cultural resources, nightlife, entertainment activities, shopping facilities, sports facilities, transportation, accommodation, food, cost performance, climate, convenience, safety, sociability, residents' hospitality, uniqueness, and service quality $[19,20]$. Beerli and Martin [25] identified nine dimensions of the perceived image of a tourism destination: natural resources, general infrastructure, tourist infrastructure, tourist leisure and recreation, culture, history and art, political and economic factors, natural environment, social environment, and atmosphere of the place. These dimensions have been widely applied in the literature. Therefore, we selected the keywords for this online text-based study from these nine dimensions.

In recent years, some scholars have conducted research on Chinese tourists' image perception of North Korea. For example, Li et al. [26] interviewed 32 Chinese tourists 
to learn about their perception of the image of North Korea as a tourist destination after North Korea's nuclear test in 2016. The results showed that after this incident, some Chinese tourists expressed concern about traveling to North Korea, but in the eyes of other Chinese tourists, North Korea has become a more mysterious country and inspired them to revisit North Korea. Li et al. [27] also conducted semi-structured interviews with 32 Chinese tourists and classified the acquired images of North Korea. The results show that North Korea's unique economic/political conditions, natural environment, infrastructure, friendly relations with China, and similarities with Chin previously constitute the image perception of North Korea by Chinese tourists. These studies used the same methods but had different research backgrounds. The objective of this study is similar to the above two studies. However, the content, perspective, and results are slightly different due to the use of different methods and analysis techniques.

\section{Data and Method}

In order to achieve the established research purpose, the research method used in this research is content analysis, which uses computer text mining technology to perform natural language processing on the collected text, and then sorts the high frequencies in the order from high to low in the article. word. Second, the changes in the frequency of occurrence of high-frequency words in the two time periods are compared (2000-2013 and 2014-2019). Finally, a semantic network analysis of the high-frequency words obtained by the statistics is carried out, and the concerns of Chinese tourists about North Korea are judged by understanding the relationship between the high-frequency words.

\subsection{Data Collection}

We collected text data (in Chinese) from comments on Chinese tourism websites about North Korea's tourism over the past 20 years (2000-2019). The seven most representative tourism websites were selected (Table 1 ). These seven websites are currently the most visited tourism websites in China, and tourists communicate with each other actively in these websites. Thus, these websites contain almost all the online comments of Chinese tourists about their travel to North Korea. The travel comments were written and uploaded to the websites by tourists after their visit to North Korea. The contents of the comments included objective facts, subjective evaluation, and emotional disclosure, enabling us to understand the perception of Chinese tourists of North Korea from various perspectives. A total of 1155 comments were included in the analysis. There were 406 comments from 2000 to 2013 and 749 comments from 2014 to 2019.

Table 1. Summary of data source for comments about North Korea's tourism.

\begin{tabular}{ccc}
\hline Number & Tourism Websites & Number of Comments \\
\hline 1 & https:/ / www.baidu.com (accessed on 1 November 2021) & 73 \\
2 & https:/ / www.mafengwo.cn/ (accessed on 1 November 2021) & 523 \\
3 & https://www.qunar.com/ (accessed on 1 November 2021) & 53 \\
4 & https://www.ly.com/ (accessed on 1 November 2021) & 19 \\
5 & https://www.ctrip.com/ (accessed on 1 November 2021) & 321 \\
6 & https://www.cncn.com/ (accessed on 1 November 2021) & 132 \\
7 & http://www.elong.com/ (accessed on 1 November 2021) & 34 \\
& Overall & 1155 \\
\hline
\end{tabular}

\subsection{Data Processing}

First, the comments that did not conform to the topic were removed (e.g., the comments like "day trip to the border between China and North Korea", "pretending to be in North Korea", etc.). Second, natural language processing was performed on the collected comments to separated them into various words. Subsequently, we deleted the less significant words (e.g., travel, today, all the time, etc.), and we standardized words with the same 
meaning but expressed differently (e.g., "Pyongyang city", "Pyongyang", and "Capital" are standardized as "Pyongyang city").

Through the above processes, the 60 keywords with the highest frequencies were selected for analysis. We classified the 60 high-frequency words into nine dimensions following Beerli and Martin [25] to investigate the Chinese tourists' overall perception of the image of North Korean tourism. To investigate the change in tourism image perception over time, we conducted frequency statistics for the keywords in two periods: 2000-2013 and 2014-2019. Each word was assigned to one of three categories: large increase (growth rate $>30 \%$ ), large decrease (growth rate $<-30 \%$ ), and no obvious change $(-10 \%<$ growth rate $<10 \%)$.

Finally, a correlation matrix of high-frequency words was generated to provide the basis for further semantic network analysis. The above data processing was performed using Textom (www.textom.co.kr (accessed on 1 November 2021)), software developed by IMC Inc., Korea.

\subsection{Semantic Network Analysis}

The purpose of semantic network analysis is to clarify the relationship between the high-frequency words and to mine the hidden information in the text. UCINET software (Analytic Technologies: http:/ / www.analytictech.com (accessed on 1 November 2021)) was used for semantic network analysis, and the UCINET integrated NetDraw program was used for the diagrams of semantic networks.

First, through the overall semantic network among all the high-frequency words, the core topic of Chinese tourists' perception of the image of North Korean tourism over the past 20 years could be intuitively observed. In the semantic network, each node represents a word, and the size of the node indicates the frequency of the word relative to other words (the larger the node, the higher the frequency of the word in the whole text). The position of the node in the network shows the centrality of the word; that is, the word in a more central position is directly connected to more other words.

Second, to find out whether there are significant differences between semantic networks of Chinese tourists' image perception during two periods, 2000-2013 and 2014-2019, we constructed two semantic networks for these two periods. We used the QAP algorithm in the social network analysis to explore the association between the two networks and to test the significance of the calculated measure of similarity.

Finally, convergence analysis of iterated correlation (CONCOR) was performed for the overall semantic network. CONCOR analysis divided the keywords in the semantic network into several groups. Each group was composed of several words (nodes) and could illustrate a topic. Each topic represents a branch of Chinese tourists' image perception of North Korean tourism.

\section{Results}

\subsection{Frequency Analysis and Classification of the Keywords}

The top 60 high-frequency words were derived from the online comments from 2000 to 2019 (Table 2). The first 10 words with the highest frequency indicate that Chinese tourists' perception of the tourism image of North Korea is concentrated on tourist facilities (Yanggakdo Hotel, Korea Hotel, subway), tourist destinations (Pyongyang city, Kaesong city, Panmunjom, Sinuiju city), tourist activities (visits), and other factors (tour guides, security checks).

The 60 high-frequency words could be divided into nine dimensions following Beerli and Martin [25] (Table 3). There were 16 high-frequency words related to "Culture, History, and Art", accounting for $26.7 \%$ of the total number of high-frequency words, suggesting that most Chinese tourists were attracted by North Korean culture, history, and art. However, there were only a few keywords describing the "general infrastructure" and the "tourist infrastructure". 
Table 2. The 60 high-frequency words.

\begin{tabular}{|c|c|c|c|c|c|c|c|c|}
\hline No. & Words & Occurrences & No. & Words & Occurrences & No. & Words & Occurrences \\
\hline 1 & Pyongyang City & 13,827 & 21 & $\begin{array}{l}\text { 38. th parallel } \\
\text { north }\end{array}$ & 1043 & 41 & Broken Bridge & 492 \\
\hline 2 & Tour Guide & 7908 & 22 & $\begin{array}{l}\text { Mansu Hill Grand } \\
\text { Monument }\end{array}$ & 1020 & 42 & Korean War & 475 \\
\hline 3 & Visit & 3000 & 23 & History & 963 & 43 & $\begin{array}{l}\text { Arirang folk } \\
\text { song }\end{array}$ & 473 \\
\hline 4 & Panmunjom & 2745 & 24 & Taedong River & 865 & 44 & Shopping & 465 \\
\hline 5 & Subway & 2498 & 25 & Monument & 865 & 45 & Naengmyeon & 462 \\
\hline 6 & $\begin{array}{l}\text { Yanggakdo } \\
\text { International } \\
\text { Hotel }\end{array}$ & 2424 & 26 & $\begin{array}{l}\text { Chinese People's } \\
\text { Volunteer Army }\end{array}$ & 826 & 46 & Cheap & 433 \\
\hline 7 & Koryo Hotel & 2285 & 27 & Beer & 789 & 47 & Civilians & 428 \\
\hline 8 & Sinuiju City & 2224 & 28 & Socialism & 760 & 48 & Safe & 413 \\
\hline 9 & Kaesong City & 2205 & 29 & Bohyeon Temple & 753 & 49 & Beauty & 411 \\
\hline 10 & Security Check & 1746 & 30 & Mount Kumgang & 734 & 50 & Curious & 395 \\
\hline 11 & Mount Myohyang & 1741 & 31 & $\begin{array}{l}\text { Korean People's } \\
\text { Army }\end{array}$ & 705 & 51 & $\begin{array}{l}\text { The War to } \\
\text { resist U.S. } \\
\text { aggression and } \\
\text { aid North } \\
\text { Korea }\end{array}$ & 371 \\
\hline 12 & Kim Jong-il & 1628 & 32 & Beauty & 680 & 52 & Kimchi & 331 \\
\hline 13 & Servicemen & 1428 & 33 & Mysterious & 671 & 53 & Casino & 291 \\
\hline 14 & Yalu River & 1344 & 34 & Pretty & 658 & 54 & $\begin{array}{l}\text { Paektu } \\
\text { Mountain }\end{array}$ & 284 \\
\hline 15 & Good & 1311 & 35 & Revolution & 630 & 55 & Enthusiasm & 256 \\
\hline 16 & Life & 1258 & 36 & Clean & 538 & 56 & Backward & 254 \\
\hline 17 & Military & 1195 & 37 & Ginseng & 525 & 57 & Street view & 247 \\
\hline 18 & Arch of Triumph & 1189 & 38 & Kim Jong-un & 513 & 58 & $\begin{array}{l}\text { Moranbong } \\
\text { Band }\end{array}$ & 225 \\
\hline 19 & Leader & 1094 & 39 & Soldier & 513 & 59 & Poverty & 181 \\
\hline 20 & Museum & 1052 & 40 & Tense & 508 & 60 & $\begin{array}{l}\text { National } \\
\text { Costume }\end{array}$ & 166 \\
\hline
\end{tabular}

When we compared the high-frequency words between the periods 2000-2013 and 2014-2019, we found that Chinese tourists' perception of the tourism image of North Korea has changed to a certain extent (Table 4). The words with a high growth rate in 2014-2019, compared to 2000-2013, were mostly related to scenic spots (Bohyeon Temple, Mount Myohyang, Mansu Hill Grand Monument) and tourism products (ginseng, beer). In contrast, the words showing the highest negative growth rate were mostly related to national culture (Arirang, national costume) and military affairs (revolution, soldiers, Korean War, socialism). These results imply that Chinese tourists' image perception of North Korean tourism is moving from culture and military affairs to topics such as scenic spots and tourism products. Furthermore, there are also many words showing little change, such as "backward", "poverty", "history", "leader", and "visit", indicating that Chinese tourists believe that North Korea is still an underdeveloped country and that visiting scenic spots is the most important tourist activity in North Korea. 
Table 3. Nine dimensions of the 60 high-frequency words.

\begin{tabular}{|c|c|c|}
\hline Dimensions & Quantity (Proportion) & Words \\
\hline Natural Resources & $7(11.67 \%)$ & $\begin{array}{l}\text { Mount Myohyang, Yalu River, } \\
\text { Taedong River, Mount Kumgang, } \\
\text { Ginseng, Broken Bridge, Paektu } \\
\text { Mountain }\end{array}$ \\
\hline General Infrastructure & $1(1.67 \%)$ & Subway \\
\hline Tourist Infrastructure & $4(6.67 \%)$ & $\begin{array}{l}\text { Tour guide, Visit, Yanggakdo } \\
\text { International Hotel, Koryo Hotel }\end{array}$ \\
\hline $\begin{array}{l}\text { Tourist Leisure and } \\
\text { Recreation }\end{array}$ & $6(10 \%)$ & $\begin{array}{l}\text { Beer, Shopping, Naengmyeon, } \\
\text { Kimchi, Casino, Moranbong Band } \\
\text { Museum, Mansu Hill Grand }\end{array}$ \\
\hline Culture, History, and Art & $16(26.67 \%)$ & $\begin{array}{l}\text { Monument, History, Arirang folk } \\
\text { song, National costume, Bohyeon } \\
\text { Temple, Arch of Triumph, 38th } \\
\text { parallel north, Kim Jong-il, Kim } \\
\text { Jong-un, Leader, Monument, Chinese } \\
\text { People's Volunteer Army, Korean } \\
\text { People's Army, Korean War, The War } \\
\text { to Resist U.S. aggression and Aid } \\
\text { North Korea }\end{array}$ \\
\hline $\begin{array}{c}\text { Political and Economic } \\
\text { Factors }\end{array}$ & $8(13.3 \%)$ & $\begin{array}{l}\text { Socialism, Revolution, Safe, Security } \\
\text { Check, Servicemen, Military, Soldier, } \\
\text { Cheap }\end{array}$ \\
\hline Natural Environment & $9(15 \%)$ & $\begin{array}{l}\text { Pyongyang City, Sinuiju City, } \\
\text { Kaesong City, Panmunjom, Street } \\
\text { View, Clean, Beautiful, Good, Pretty, }\end{array}$ \\
\hline Social Environment & $6(10 \%)$ & $\begin{array}{l}\text { Civilians, Life, Beauty, Backward, } \\
\text { Poverty, Enthusiasm }\end{array}$ \\
\hline Atmosphere of the Place & $3(5 \%)$ & mysterious, tense, curious \\
\hline
\end{tabular}

Table 4. The change in frequency of the keywords from text data on Chinese tourism websites $b$ between 2000-2013 and 2014-2019.

\begin{tabular}{lll}
\hline No. & Word & Growth Rate \\
\hline Large increase & Bohyeon Temple & \\
1 & Koryo Hotel & $248.0 \%$ \\
2 & Moranbong Band & $156.9 \%$ \\
3 & Kim Jong-un & $137.4 \%$ \\
4 & Street view & $98.0 \%$ \\
5 & Ginseng & $96.3 \%$ \\
6 & Mount Myohyang & $93.6 \%$ \\
7 & Mansu Hill Grand Monument & $91.4 \%$ \\
8 & Subway & $89.6 \%$ \\
9 & Beer & $74.3 \%$ \\
10 & & $59.0 \%$ \\
\hline Large decrease & Arirang folk song & \\
1 & Civilians & $-60.6 \%$ \\
2 & Casino & $-59.9 \%$ \\
3 & Kim Jong-il & $-56.2 \%$ \\
4 & Beauty & $-43.5 \%$ \\
5 & Revolution & $-34.7 \%$ \\
6 & Soldier & $-34.5 \%$ \\
7 & Korean War & $-34.4 \%$ \\
8 & National costume & $-34.4 \%$ \\
9 & & $-31.2 \%$ \\
\hline
\end{tabular}




\subsection{Semantic Network Analysis}

The results of the semantic network analysis show that the online comments were mainly formed by nodes such as Pyongyang city, tour guide, Panmunjom, Yanggakdo International Hotel, visit, Sinuiju city, and Kaesong city (Figure 1). Therefore, the items that made the deepest impression on Chinese tourists during their trip to North Korea were their visits to particular destinations (Pyongyang city, Kaesong city, Sinuiju city, Panmunjom, North Korea) accompanied by a tour guide. Moreover, most Chinese tourists stayed in the Yanggakdo International Hotel during their stay in North Korea.

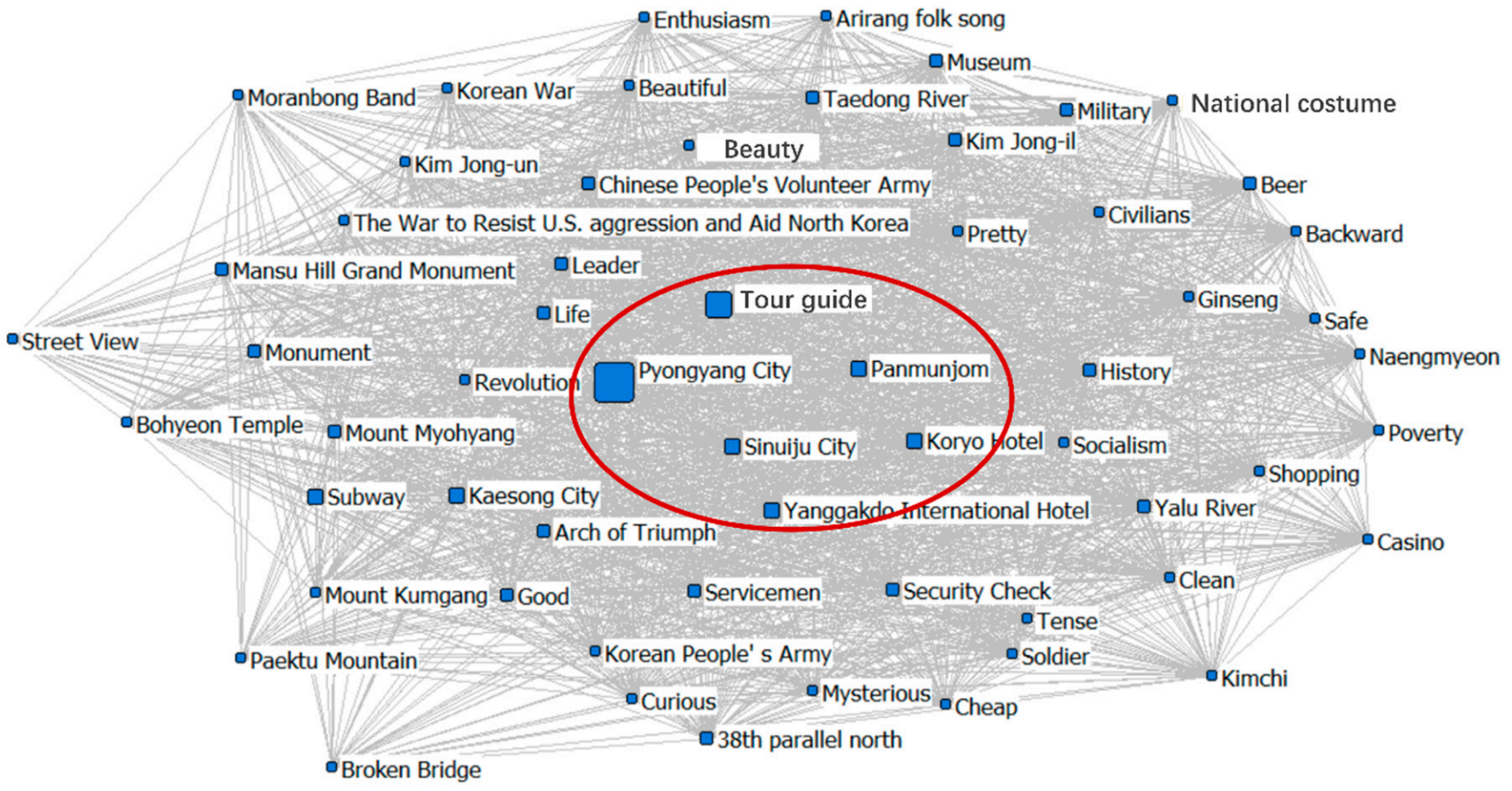

Figure 1. Semantic network analysis (2000-2019) on text data from Chinese tourism websites.

\subsection{QAP Analysis}

The QAP analysis of the semantic networks during the two time periods, 2000-2013 and 2014-2019, shows that the correlation between the two semantic networks was 0.879 , and the significance was 0.0002 (Figure 2). Therefore, the two semantic networks correlate significantly, suggesting no fundamental change in Chinese tourists' perception of the tourism image of North Korea.

\subsection{Convergence Analysis of Iteration Correlation}

The semantic networks from 2000-2013 and 2014-2019 show a high correlation. Therefore, we only performed the CONCOR analysis on the semantic network for the combined time periods (Figure 3). In Figure 3, each cluster (containing several words) represents a topic, which indicates a branch of Chinese tourists' perception of the image of North Korean tourism. The results show that the keywords in the online texts could be divided into six clusters:

(1) Representative scenic spots and tourist infrastructure: Around words such as "tour guide" and "visit", there are many words related to scenic spots (e.g., "Mount Myohyang", "Mount Kumgang", "Arch of Triumph", "Bohyeon Temple") and tourist infrastructure (e.g., Yanggakdo International Hotel, subway). These clusters indicate that Chinese tourists, after their trip, objectively describe and evaluate several famous North Korean scenic spots.

(2) The Korean War: This cluster is composed of a large number of words describing the Korean War (e.g., 38th parallel north, Yalu River, soldier), and the related tourist destinations (e.g., Panmunjom, where the 1953 Korean Armistice Agreement that paused 
the Korean War was signed). As a result of China's military support during this war, China and North Korea established a deep relationship. Therefore, the Korean War is an important topic for Chinese tourists.

(3) Kaesong city: Kaesong was the capital of all Korea during the Koryo Dynasty, and it was recognized as a World Cultural Heritage site in 2013. As a famous North Korean tourist destination, Kaesong was one of the most frequently mentioned clusters by Chinese tourists due to its history and culture. For example, the Koryo museum is located in Kaesong. Kaesong is also the place of origin of ginseng.

(4) Pyongyang City: Chinese tourists described seeing "servicemen" and "beauty" in North Korea's capital, "Pyongyang City". Moreover, North Korea has a strict security system for foreign tourists due to the high frequency of "security checks" and the "tense" atmosphere.

(5) People's lives: This cluster centered on the words "civilians", "national costume", "enthusiasm", "curious", and "poverty", representing the view that Chinese tourists are curious about the daily life of ordinary people in North Korea, and that they think of North Korea as a poor country. In addition, the high frequency of the names "Kim Jong-il" and "Kim Jong-un" shows that the two generations of North Korean leaders made an impression on Chinese tourists.

(6) Other experiences: This cluster comprised of food and drink (kimchi, naengmyeon, beer), "shopping", and entertainment ("casino").

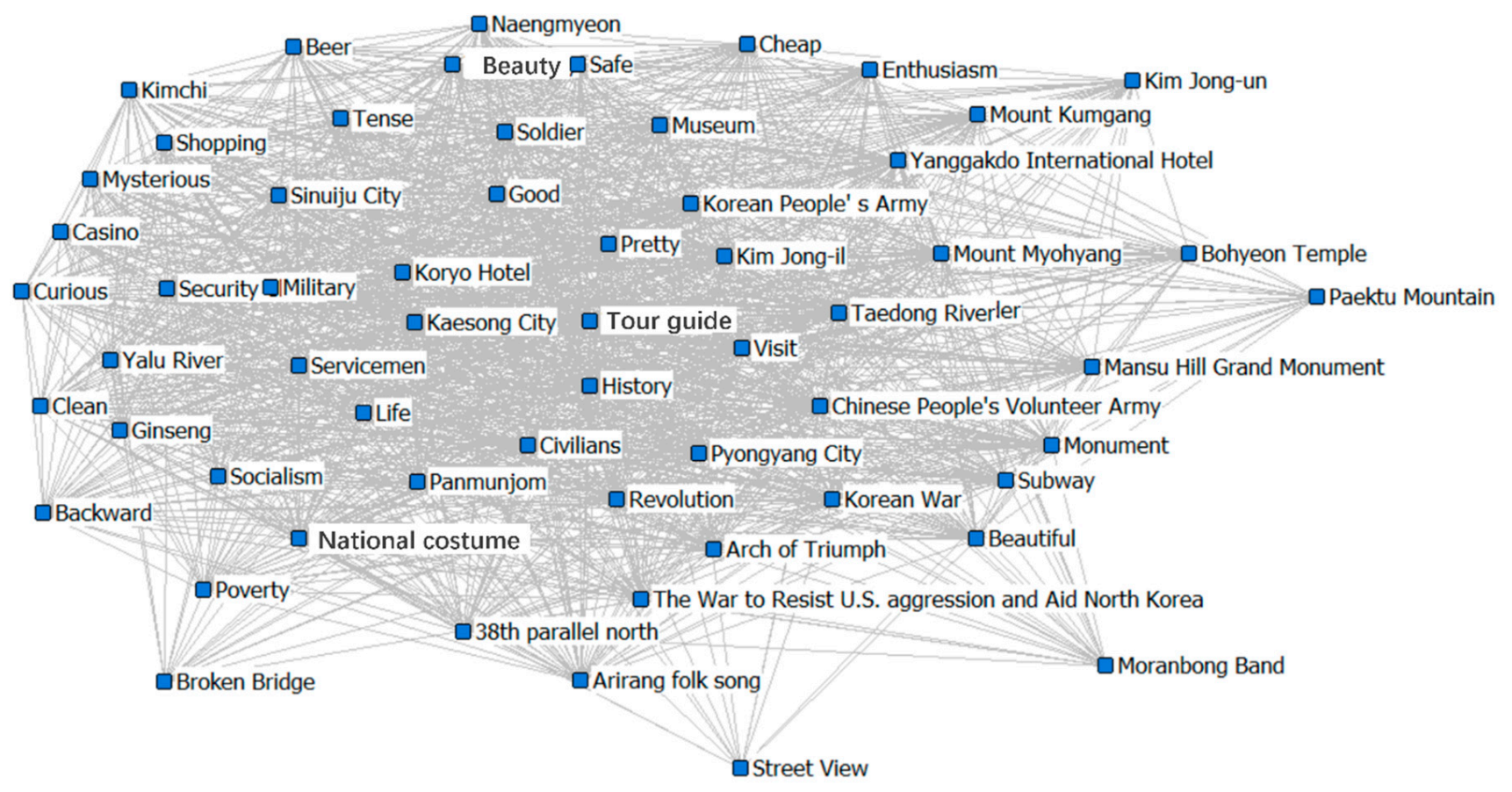

(a)

Figure 2. Cont. 


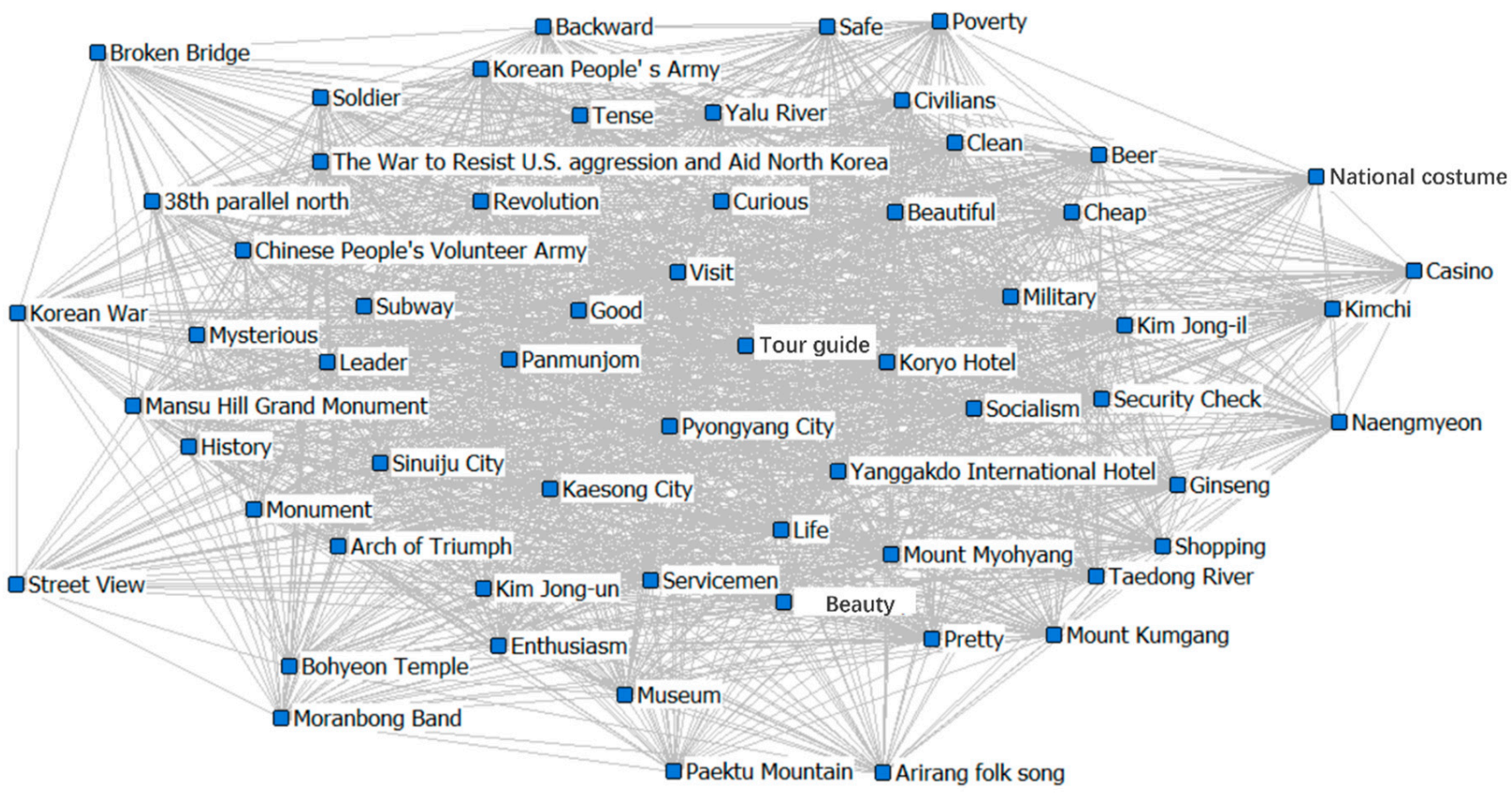

(b)

Figure 2. Semantic network analysis on text data from Chinese tourism websites during two time periods, (a) 2000-2013 and (b) 2014-2019.

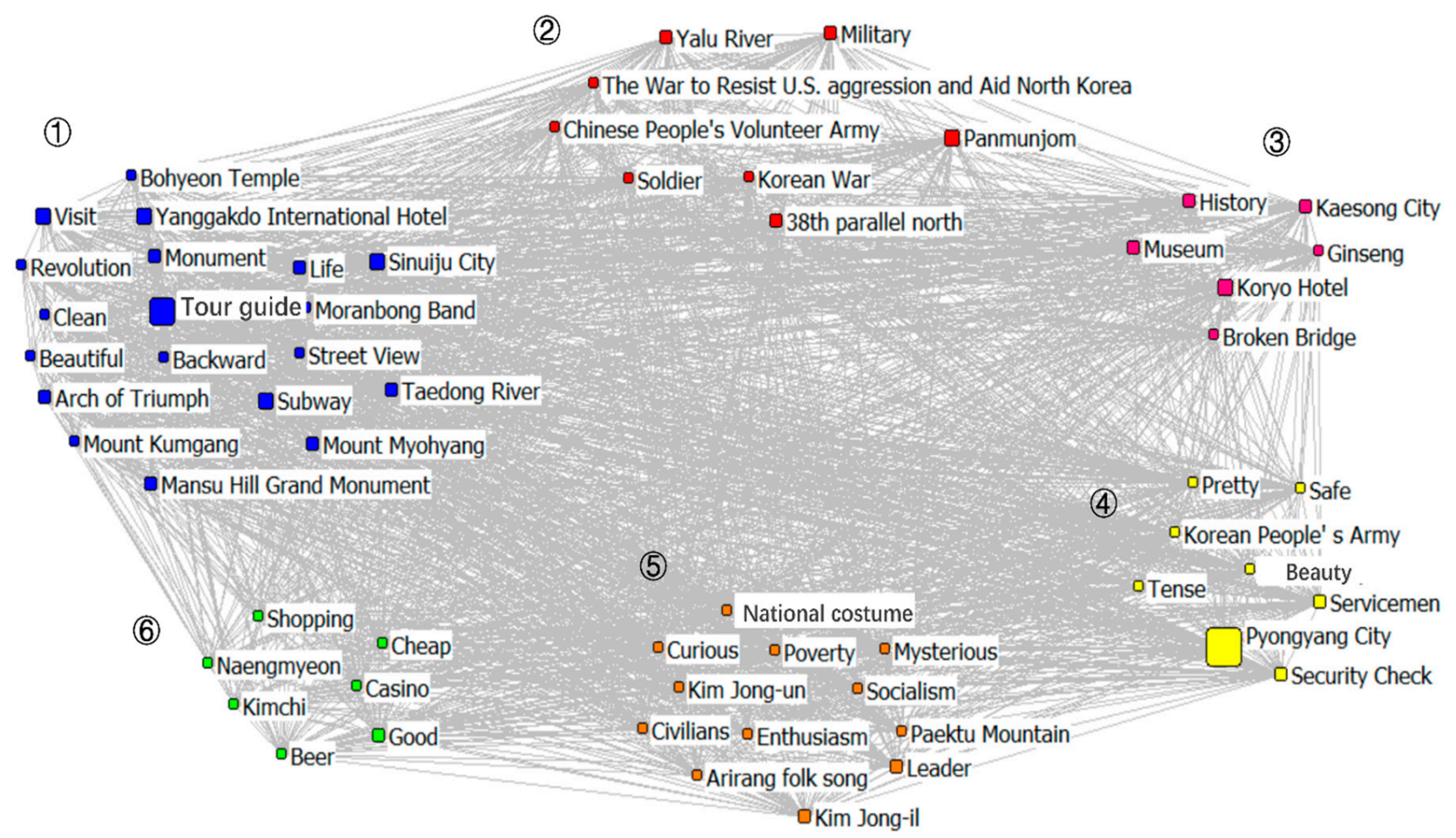

Figure 3. Visualization of the result of convergence analysis of iteration correlation. 


\section{Discussion and Conclusions}

\subsection{Discussion}

\subsubsection{The Problem in North Korea Tourism}

First, in North Korea, tourism resources are too similar, and there is a lack of competition among tourism products. The high-frequency words related to scenic spots and historical experiences were the most abundant, but the words related to entertainment were extremely rare, suggesting that the tourism industry in North Korea is still at the sightseeing level. Moreover, North Korean tourism is limited to group tours accompanied by tour guides throughout the whole journey. It is not possible to see the country as an independent tourist.

Second, the products that are competitive are losing their influence. The Korean War, as a topic that attracts the attention of Chinese tourists, gradually fell out of favor. The frequency of words such as "Korean War", "soldier", and "socialism" decreased in recent years. If tourism resources other than those related to the Korean War cannot be effectively developed, the competitiveness of North Korea as a tourist destination will continue to decline.

Third, the integration of culture and tourism products is insufficient. North Korea has a unique national culture in terms of folk customs, food, clothing, and entertainment. However, it is difficult to find its unique competitive advantage in the analysis results. For example, "Arirang folk song" and "national costume" have fallen in frequency in recent years, and words like "seafood" are not mentioned by tourists. Therefore, the North Korean government has not promoted the integration of national culture and tourism products.

Fourth, the balance between "mystery" and "opening up" should be reconsidered. Based on the high-frequency words, we found that the charm that distinguishes North Korea from other tourist destinations lies in its "mystery". Yet, if North Korea wants more tourists to visit, the country needs to open up. However, increased tourist numbers would cause the country to lose its mystery. In this contradictory reality, the North Korean government should balance "opening up" and "mystery" when developing its tourism industry. This 'balance' could be achieved in two ways. First, North Korea could simplify entry procedures to express a positive attitude towards opening up and could step up the construction of infrastructure to meet more tourists' requirements. Second, with such an opening-up policy, it is necessary to ensure a continuous sense of "mystery". Therefore, the policy of "limited ban" and "personal travel" can be maintained, but the policy of "limited ban" and "personal travel" can be retained. Although these policies will have a certain negative impact on tourists' travel experience, they can strengthen its uniqueness and thus enhance the impression of tourists on North Korea.

\subsubsection{Policy Advice for North Korean Tourism}

First, the North Korean tourism administration should develop more cultural and entertainment industries and provide new tourism modes, thereby dealing with the problems of a unitary tourism mode. Tourism in North Korea is tightly controlled by the North Korean government. Apart from visits to scenic spots, there are few other things of interest to tourists. Therefore, the North Korean tourism administration should develop other related industries such as food, housing, transportation, shopping, and entertainment. Furthermore, all tourism is organized by state-owned tourism bureaus. Tourists must go on guided tours. In an era in which tourism is rarely subject to national boundaries, the North Korean government should allow tourists to travel freely.

Second, the North Korean tourism administration should cooperate with Chinese tourism enterprises to promote and spread the national culture. Table 3 shows that mentions of the "Moranbong Band" are increasing. The Moranbong Band is an all-female North Korean music group whose original members were selected by the country's supreme leader Kim Jong-un. To attract more tourists, North Korea should increase the number of performances and the publicity for the Moranbong Band. The Moranbong Band should give regular public performances and participate in live broadcasts on social media. Over- 
all, there is a need to use network media to effectively spread the tourism-related culture of North Korea.

Third, "opening up" is an inevitable choice if the tourism industry is to be promoted. However, due to the particularity of North Korea's political situation, its "mystery" has lasted a long time. The removal of its "mystery" represents a declaration to the world, on the part of North Korea, about its openness. It could begin by relaxing visa policies for foreign tourists and guaranteeing freedom of activities for tourists in North Korea.

\subsubsection{Further Research Directions}

This study found that the mystery of North Korea is the trait that attracts Chinese tourists and that tourism content is relatively simple in North Korea. This is consistent with the research results of Li and Ryan [14]. However, the main research object of this study is Chinese tourists. Future research could expand to include tourists from other regions, such as Europe, America, and Africa. In addition, it is necessary to conduct questionnaire surveys and carry out empirical research on foreign tourists traveling to North Korea.

\subsection{Conclusions}

This study investigated 1155 online comments over the past 20 years related to the subjective emotions and objective evaluations of Chinese tourists traveling to North Korea. We used text mining and semantic network analysis to reach the following conclusions:

First, according to the analysis of high-frequency words, the tourist activities of Chinese tourists in North Korea mainly consisted of visiting scenic spots, although other aspects were also mentioned. In addition, the Korean War is mentioned frequently, indicating that many Chinese people travel to North Korea because they wanted to go to the place where their ancestors fought in the war. In addition, the most common word used by Chinese tourists to describe North Korea is "mystery", an indication of the strongest impression left by North Korea on Chinese tourists. In recent years, the attention of Chinese tourists to North Korea's past military actions (revolution, soldiers, the Korean War, socialism) began to shift to scenic spots and tourism products. Therefore, Chinese tourists' motivation for visiting North Korea has begun to change.

Second, based on the semantic network analysis on the high-frequency words, the core topics of Chinese tourists describing North Korea tourism focus mainly on Pyongyang city, Sinuiju city, Kaesong city, Panmunjom, tour guide, visit, Yanggakdo International Hotel, etc. Therefore, the core focus of tourism in North Korea is visiting the central cities and the famous scenic spots accompanied by a tour guide. In the two periods of 2000-2013 and 2014-2019, there was no significant change in the fundamental structure of Chinese tourists' image of tourism in North Korea.

Third, the clusters (based on the CONCOR analysis) that constitute the image of tourism in North Korea involve representative scenic spots and tourist infrastructure, citizens' lives, the Korean War, Kaesong city, Pyongyang city, and other experiences. In other words, these six topics are the most commonly discussed by Chinese tourists after their trip to North Korea.

Author Contributions: Data curation, R.L.; formal analysis, H.W.; methodology and project administration, H.Z.; software, H.W.; writing—original draft R.L.; writing—review and editing, H.Z. All authors have read and agreed to the published version of the manuscript.

Funding: This research was funded by the project of the Chinese Academy of Sciences (grant number: KGFZD-135-17-009-1).

Institutional Review Board Statement: Not applicable.

Informed Consent Statement: Not applicable.

Data Availability Statement: Not applicable.

Conflicts of Interest: The authors declare no conflict of interest. 


\section{References}

1. Zhou, J. Tourism Apperceiving Image and Creation of Tourist Destination's Image. J. Guilin Inst. Tour. 2007, 18, 353-356.

2. Crompton, J. Motivations for pleasure vacation. Ann. Tour. Res. 1979, 6, 408-424. [CrossRef]

3. Zhang, X.; Chen, Z. Measurement Tool of National Tourism Image and Its' Application. Future Dev. 2017, 3, 92-98. (In Chinese)

4. Zhang, H.; Cho, T.; Wang, H. The Impact of a Terminal High Altitude Area Defense Incident on Tourism Risk Perception and Attitude Change of Chinese Tourists Traveling to South Korea. Sustainability 2020, 12, 7. [CrossRef]

5. Shin, J. Tourism image on KOREA and JAPAN. Int. J. Tour. Hosp. Res. 1995, 5, 75-86.

6. Dwivedi, M. Online destination image of India: A consumer based perspective. Int. J. Contemp. Hosp. Manag. 2009, 21, 226-232. [CrossRef]

7. Govers, R.; Go, F. Projected destination image online: Website content analysis of pictures and text. Inf. Technol. Tour. 2005, 7, 73-89. [CrossRef]

8. Zhou, L. Online rural destination images: Tourism and rurality. J. Destin. Mark. Manag. 2014, 3, 227-240. [CrossRef]

9. Kladou, S.; Mavragani, E. Assessing destination image: An online marketing approach and the case of Trip Advisor. J. Destin. Mark. Manag. 2015, 4, 187-193.

10. Son, K.-J.; Cho, I.-H.; Kim, C.-W.; Jun, C.-N. Design and Implementation of Hadoop-based Platform “Textom" for Processing Big-data. Korea Contents Assoc. 2015, 5, 297-298.

11. Dilley, R.S. Tourist brochures and tourist images. Can. Geogr. 1986, 30, 59-65. [CrossRef]

12. Stepchenkova, S.; Morrison, A.M. The destination image of Russia: From the online induced perspective. Tour. Manag. 2006, 27, 943-956. [CrossRef]

13. Choi, S.; Lehto, X.Y.; Morrison, A.M. Destination image representation on the web: Content analysis of Macau travel related websites. Tour. Manag. 2007, 28, 118-129. [CrossRef]

14. Li, F.; Ryan, C. Chinese Tourists' Motivations and Satisfaction of Visiting North Korea. Asia Pac. J. Tour. Res. 2015, 12, 1313-1331. [CrossRef]

15. Hunt, J.D. Image: A Factor in Tourism; Colorado State University: Fort Collins, CO, USA, 1971; p. 207.

16. Baloglu, S.; McCleary, K.W.U.S. International pleasure travelers' image of four Mediterranean destinations: A comparison of visitors and non-visitors. J. Travel Res. 1999, 38, 144-152. [CrossRef]

17. Echtner, C.M.; Ritchie, J.R.B. The meaning and measurement of destination image. J. Tour. Stud. 1991, 2, 2-12.

18. Gertner, D. Unfolding and configuring two decades of research and publications on place marketing and place branding. Place Branding Public Dipl. 2011, 7, 91-106. [CrossRef]

19. Mayo, E.J. Regional images and regional travel behaviour. In Proceedings of the Travel Research Association Fourth Annual Conference Proceedings, Sun Valley, ID, USA, 12-15 August 1973; pp. 211-218.

20. Crompton, J.L. An assessment of the image of Mexico as a vacation destination and the influence of geographical location upon that image. J. Travel Res. 1979, 17, 18-23. [CrossRef]

21. Baloglu, S.; McCleary, K.W. A Model of Destination Image Formation. Ann. Tour. Res. 1999, 26, 868-897. [CrossRef]

22. Kim, H.; Richardson, S.L. Motion pi cture im pact son destination images. Ann. Tour. Res. 2003, 30, 216-237. [CrossRef]

23. $\mathrm{Bi}, \mathrm{C}$. The Impact of Destination Choice Attributes and Korean Tourist Destination Image on Behavior Intention of Chinese Students. Master's Thesis, Honam University, Gwangju, Korea, 2011.

24. Grosspietsch, M. Perceived and projected images of Rwanda: Visitor and international tour operator perspectives. Tour. Manag. 2006, 27, 225-234. [CrossRef]

25. Beerli, A.; Martin, J.D. Factors Influencing Destination Image. Annu. Tour. Res. 2004, 31, 657-681. [CrossRef]

26. Li, F.; Wen, J.; Ying, T. The influence of crisis on tourists' perceived destination image and revisit intention: An exploratory study of Chinese tourists to North Korea. J. Destin. Mark. Manag. 2017, 8, 104-111. [CrossRef]

27. Li, Z.; Li, F.S.; Ryan, C. Perceiving North Korea through Chinese tourists' eyes. Tour. Rev. 2020, ahead-of-print. [CrossRef] 